\title{
Pharaoh Ant, Monomorium pharaonis (Linnaeus) (Insecta: Hymenoptera: Formicidae) ${ }^{1}$
}

\author{
J. C. Nickerson, D. L. Harris and T. R. Fasulo²
}

\section{Introduction}

The ant, Monomorium pharaonis (Linnaeus), is commonly known as the Pharaoh ant. The name possibly arises from the mistaken tradition that it was one of the plagues of ancient Egypt (Peacock et al. 1950). This ant is distributed worldwide, is one of the more common household ants, and carries the dubious distinction of being the most difficult household ant to control.

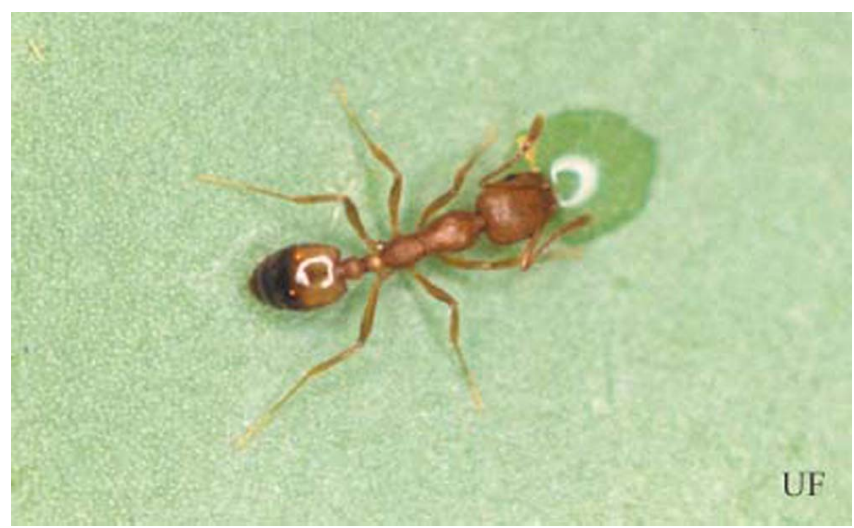

Figure 1. Dorsal view of a Pharaoh ant worker, Monomorium pharaonis (Linnaeus), feeding on bait. Credits: James Castner, University of Florida
In some of the older literature this species was commonly referred to as the "Pharaoh's ant." This is now incorrect, if it ever was, as the correct common name is "Pharaoh ant," as determined by the Committee on Common Names of Insects of the Entomological Society of America (Bosik 1997). It is only mentioned here as the junior author still sees "Pharaoh's ant" on the Web and in industry publications.

\section{Distribution}

Monomorium pharaonis (Linnaeus) has been carried by commerce to all inhabited regions of the earth (Wheeler 1910). This ant, which is probably a native of Africa, does not nest outdoors except in southern latitudes and has been able to adapt to field conditions in southern Florida (Creighton 1950). In colder climates, it has become established in heated buildings.

1. This document is EENY-290 (originally published as DPI Entomology Circular 256), one of a series of Featured Creatures from the Entomology and Nematology Department, Florida Cooperative Extension Service, Institute of Food and Agricultural Sciences, University of Florida. Published: June 2003. This document is also available on Featured Creatures Website at http://creatures.ifas.ufl.edu. Please visit the EDIS Website at http://edis.ifas.ufl.edu. Additional information on these organisms, including many color photographs, is available at the Entomology and Nematology Department website at http://entnemdept.ifas.ufl.edu/.

2. J.C. Nickerson and D.L. Harris, Florida Department of Agriculture and Consumer Services, Division of Plant Industry; and T.R. Fasulo, Department of Entomology and Nematology, Institute of Food and Agricultural Sciences, University of Florida, Gainesville, FL.

The Institute of Food and Agricultural Sciences (IFAS) is an Equal Employment Opportunity - Affirmative Action Employer authorized to provide research, educational information and other services only to individuals and institutions that function without regard to race, creed, color, religion, age, disability, sex, sexual orientation, marital status, national origin, political opinions or affiliations. For information on obtaining other extension publications, contact your county Cooperative Extension Service office. Florida Cooperative Extension Service / Institute of Food and Agricultural Sciences / University of Florida / Larry R. Arrington, Interim Dean 


\section{Description}

The workers of Monomorium pharaonis (L.) while monomorphic (same size), do vary slightly in length and are approximately 1.5 to $2 \mathrm{~mm}$ long (Haack and Granovsky 1990). The antennae have 12 segments with each segment of the 3-segmented antennal clubs increasing in size toward the apex of the club (Smith and Whitman 1992). The eye is comparatively small, with approximately six to eight ommatidia across the greatest diameter. The prothorax has subangular shoulders, and the thorax has a well- defined mesoepinotal impression. Erect hairs are sparse on the body, and body pubescence is sparse and closely appresssed. The head, thorax, petiole and postpetiole (the petiole, or the petiole and postpetiole, in ants is also called the pedicel) are densely (but weakly) punctulate, dull, or subopaque. The clypeus, gaster, and mandibles are shiny. The body color ranges from yellowish or light brown to red (Smith 1965), with the abdomen often darker to blackish (Smith and Whitman 1992). A stinger is present but is rarely exserted (Haack and Granovsky 1990).

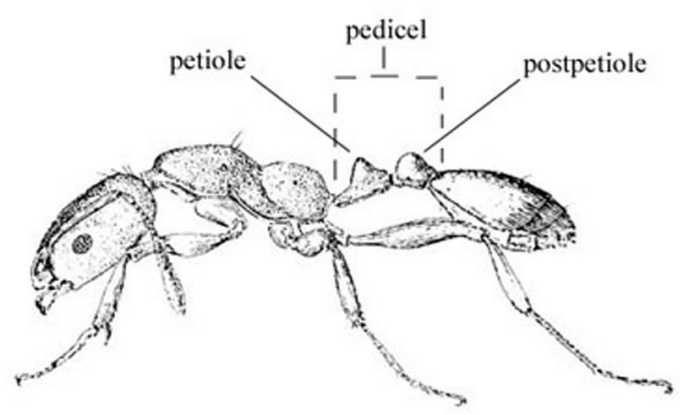

Figure 2. Worker. Credits:

\section{Biology and Nesting Habits}

The Pharaoh ant colony consists of queens, males, workers, and immature stages (eggs, larvae, pre- pupae, and pupae). Nesting occurs in inaccessible warm $\left(80\right.$ to $\left.86^{\circ} \mathrm{F}\right)$, humid $(80 \%)$ areas near sources of food and/or water, such as in wall voids. The size of the colony tends to be large but can vary from a few dozen to several thousand or even several hundred thousand individuals. Approximately 38 days are required for development of workers from egg to adult.

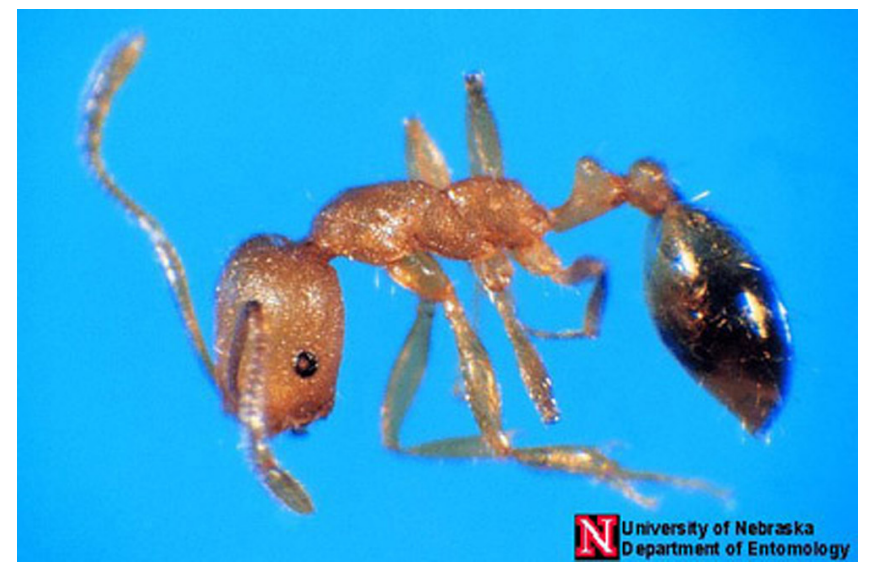

Figure 3. Lateral view of a Pharaoh ant worker, Monomorium pharaonis (Linnaeus). Credits: Jim Kalisch, University of Nebraska - Lincoln

Mating takes place in the nest, and no swarms are known to occur. Males and queens usually take 42 days to develop from egg to adult. The males are the same size as the workers ( $2 \mathrm{~mm})$, are black in color and have straight, not elbowed, antennae. Males are not often found in the colony. The queens are about 4 $\mathrm{mm}$ long and are slightly darker than the workers (Smith and Whitman 1992). Queens can produce 400 or more eggs in batches of 10 to 12 (Peacock et al. 1950). Queens can live four to 12 months, while males die within three to five weeks after mating (Smith and Whitman 1992).

Part of the success and persistence of this ant undoubtably relates to the budding or splitting habits of the colonies. Numerous daughter colonies are produced from the mother colony when a queen and a few workers break off and establish a new colony. Even in the absence of a queen, workers can develop a queen from the brood which is transported from the mother country. In large colonies there may be as many as several hundred reproductive females (Smith and Whitman 1992).

\section{Economic Importance}

The Pharaoh ant is a major indoor pest in the United States. The ant has the ability to survive most conventional household pest control treatments and to establish colonies throughout a building. More than just the food it consumes or spoils, this ant is considered a serious pest simply due to its ability for "getting into things." Pharaoh ants are reported to have even penetrated the security of recombinant DNA laboratories (Haack and Granovsky 1990). 
In some areas, this ant has become a major pest of residences, commercial bakeries, factories, office buildings, apartments, and hospitals or other areas where food is handled. Infestations in hospitals have become a chronic problem in Europe (Erodes et al. 1977) and the United States. In Texas, Wilson and Booth (1981) reported an extensive infestation throughout a seven-floor medical center. In antinfested hospitals, burn victims and newborns are subjected to increased risk because the Pharaoh ant can transmit over a dozen pathogenic pathogens such as Salmonella spp., Staphylococcus spp., and Streptococcus spp. (Beatson 1977, Haack and Granovsky 1990, Smith and Whitman 1992). Pharaoh ants have been observed seeking moisture from the mouths of sleeping infants and from in-use IV bottles (Smith and Whitman 1992).

This ant infests almost all areas of a building where food is available and infests many areas where food is not commonly found. Pharaoh ants have a wide preference in the types of food consumed. In infested areas, if sweet, fatty, or oily foods are left uncovered for only a short period of time, one can likely find a trail of Pharaoh ants to the food. As a consequence, they cause much food to be discarded due to contamination. Owners have been known to consider selling their homes because of the ravages of this pest (Smith 1965).

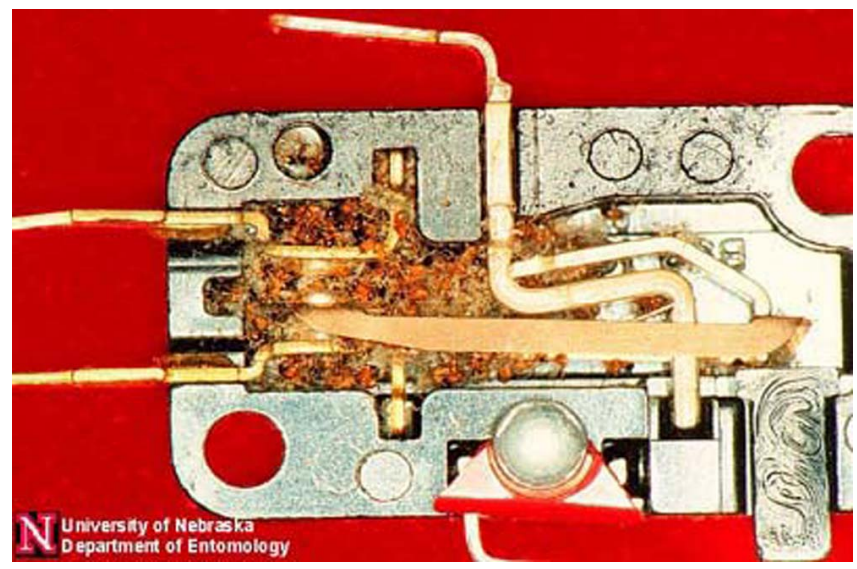

Figure 4. Pharaoh ants, Monomorium pharaonis (Linnaeus), in an electrical switch mechanism. Credits: Jim Kalisch, University of Nebraska - Lincoln

\section{Survey and Detection}

Workers of the Pharaoh ant can often be observed on their feeding trails, often using wiring or hot water pipes to travel through walls and between floors. Once a worker has located a food source, it lays a chemical trail from the food to the nest (Haack and Granovsky 1990). These ants are attracted to sweet and fatty foods, which may be used to determine their presence. Pharaoh ants will nest in the oddest places, such as between sheets of stationary, layers of bed linen and clothes, in appliances, or even piles of trash (Ebeling 1978).

Pharaoh ants may be confused with thief ants, bigheaded ants, firs ants and several other species of small pale ants. However, thief ants have just 10 segments in their antennae with only a 2-segmented club. Bigheaded and fire ants have a pair of spines on the thorax, while other small pale ants have only a one segment on the pedical (smith and Whitman 1992).

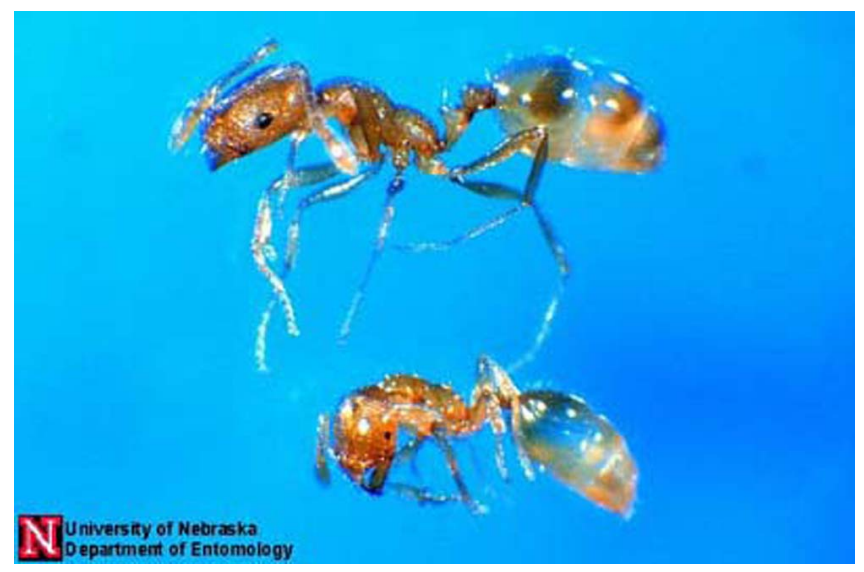

Figure 5. A comparison of the bodies of workers of the Pharaoh ant (top), Monomorium pharaonis (Linnaeus), and the thief ant (bottom), Solenopsis molesta (Say). Credits: Jim Kalisch, University of Nebraska - Lincoln

\section{Management}

Control of Pharaoh ants is difficult, due to their nesting in inaccessible areas. Treatment must be thorough and complete at all nesting sites, as well as the foraging area. Thus, treatment must include walls, ceilings, floor voids, and electrical wall outlets. Baits are now the preferred method of control for Pharaoh ants and several baits (insecticides) are labeled for indoor ant control. A Pharaoh ant infestation of a multifamily building requires treatment of the entire building to control the infestation. Ants nesting on the outside may be controlled by also using a perimeter barrier treatment (Smith and Whitman 1992). 


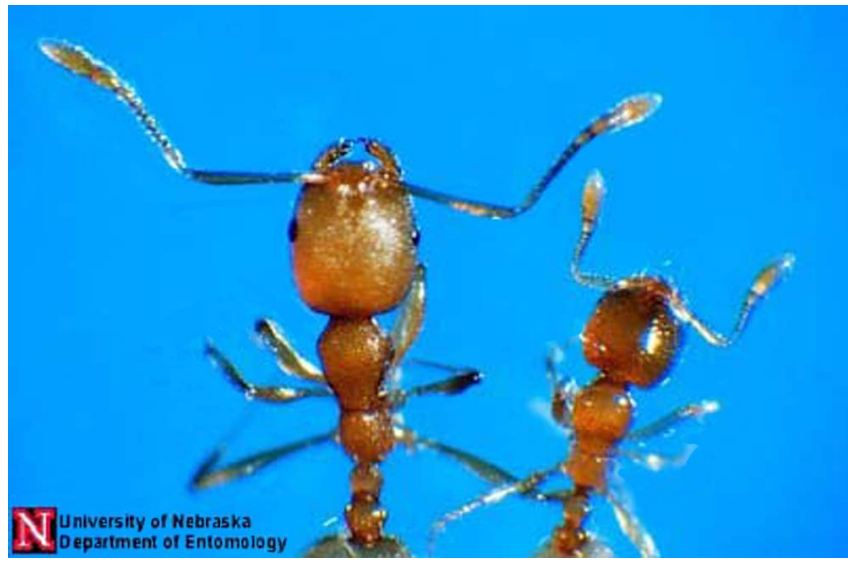

Figure 6. A comparison of the heads of workers of the Pharaoh ant (left), Monomorium pharaonis (Linnaeus), and the thief ant (right), Solenopsis molesta (Say). Credits: Jim Kalisch, University of Nebraska - Lincoln

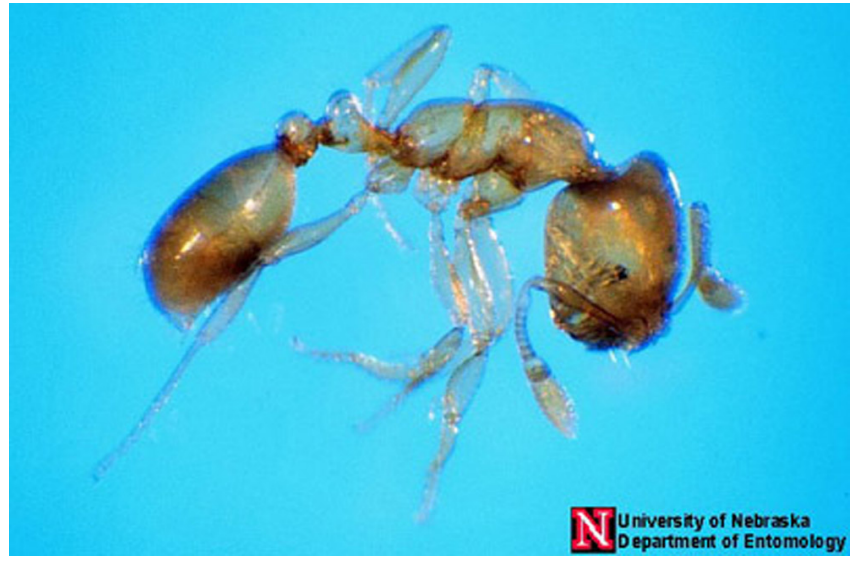

Figure 7. A thief ant worker, Solenopsis molesta (Say). Credits: Jim Kalisch, University of Nebraska - Lincoln

Baits cannot be placed in just any location and be expected to work. Pharaoh ant trails and their resources (both food and water) must be located for proper placement of baits and effective control (Klotz et al. 2000). Non-repellent baits (such as boric acid, hydramethylon or sulfonamide) should be used, as repellent baits can worsen the situation by causing the colony to fracture and bud. As a result, ant activity will briefly diminish as as the new colonies establish themselves, then again become a problem as the foragers resume activity (Smith and Whitman 1992).

In addition, insect growth regulators (IGR) are marketed for indoor control of Pharaoh ants. The IGR is used as a bait, and ants must be allowed to transport the bait back to their nests. The IGR prevents the production of worker ants and sterilizes the queen. Therefore, it is necessary to allow up to several weeks or months (depending on the size of the colonies or number of colonies) for ants to die naturally with the use of IGR.

For more management information, please see the Insect Management Guide for Ants (http://edis.ifas.ufl.edu/IG080).

\section{Selected References}

Beatson SH. 1972. Pharaoh ants as pathogen vectors in hospitals. Lancet 1: 425-427.

Bosik JJ. 1997. Common Names of Insects and Related Organisms. Entomological Society of America, Lanham, MD

Creighton WS. 1950. The ants of North America. Bulletin of the Museum of Comparative Zoology 104: 1-585.

Drees BM, Jackman J. (1999). Pharaoh ant. A Field Guide to Common Texas Insects. http://insects.tamu.edu/images/insects/fieldguide/ cimg358.html (29 May 2003).

Ebeling W. (1978). Urban Entomology. Agricultural Sciences Publications, University of California, Berkeley, CA.

Erdos MD, Koncz A. 1977. Experience in the control of Pharaoh's ants in Hungary. International Pest Control 19: 12-13.

Haack KD, Granovsky TA. (1990). Ants. In Handbook of Pest Control (Story K, Moreland D (eds.)). Franzak \& Foster Co., Cleveland, OH. pp. 415-479.

Klotz J, Williams D, Reid B, Vail K, Koehler P. (September 2000). Ant trails: a key to management with baits. EDIS. http://edis.ifas.ufl.edu/IG123 (29 May 2003).

Koehler PG, Short DE, Fasulo TR. (2002). Pests In and Around the Home. UF/IFAS. SW-126.

Lyon WF. (Unknown). Pharaoh ant. Factsheet. http://ohioline.osu.edu/hyg-fact/2000/2136.html (29 May 2003). 
Peacock AD, Hall DW, Smith IC, Goodfellow A.

1950. The biology and control of the ant pest

Monomorium pharaonis (L.). Department of

Agriculture of Scotland Miscellaneous Publications

17. $51 \mathrm{p}$.

Smith EH, Whitman RC. 1992. Field Guide to Structural Pests. National Pest Management

Association, Dunn Loring, VA.

Smith MR. 1965. House-infesting Ants of the Eastern United States: Their Recognition, Biology, and Economic Importance. USDA-ARS Technical Bulletin 1326. 105 p.

Wheeler WM. 1910. Ants: Their Structure, Development, and Behavior. Columbia University Press. NY. 633 p.

Wilson GR, Booth MJ. 1981. Pharaoh Ant Control with IGR in Hospitals. Pest Control 49: 14-19, 74. 